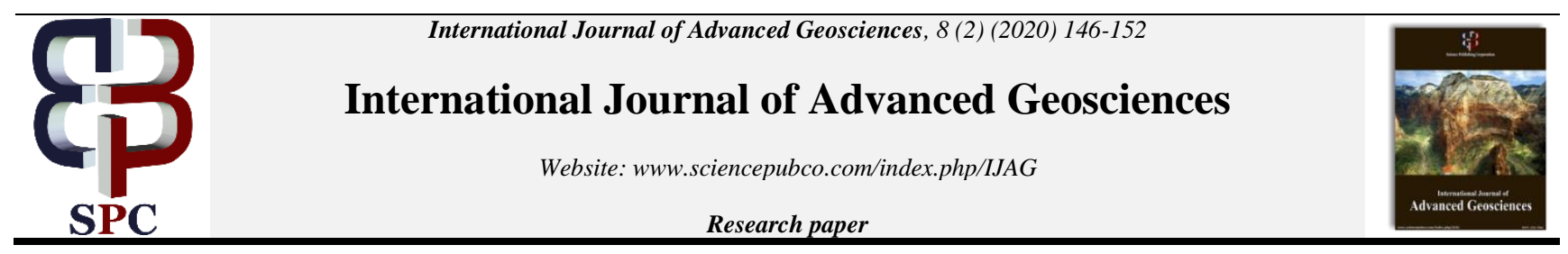

\title{
Application of electrical resistivity tomography for mapping gold mineralization potential in Iperindo, Ilesha schist belt, southwestern Nigeria
}

\author{
Olawale OlakunleOsinowo ${ }^{1,2}$, Ahmed Kehinde Usman ${ }^{2,3}$, Ayotunde Allen Omitoogun ${ }^{1,2}$ \\ ${ }^{1}$ Department of Geology, University of Ibadan, Ibadan, Nigeria \\ ${ }^{2}$ Pan African University, Earth and Life Sciences Institute, University of Ibadan, Ibadan, Nigeria \\ ${ }^{3}$ Department of Physics, Ahmadu Bello University, Kaduna, Nigeria \\ *Corresponding author E-mail:wale.osinowo@ui.edu.ng
}

\begin{abstract}
This study applied Electrical Resistivity Tomography geophysical investigation technique to evaluate the gold mineralization potential of Iperindo in Ilesha Schist Belt, southwestern Nigeria, where commercial exploitation capable of generating revenue and employment for the inhabitants has been challenged by lack / inadequate subsurface geological/geophysical information. The filtered and inverted electrical resistivity data acquired through five (5) $336 \mathrm{~m}$ long E - W trending profiles, established $10 \mathrm{~m}$ apart from each other, delineate isolated near surface but thick (> $30 \mathrm{~m}$ ) low resistivity zones, especially at the eastern and western ends of the study area. Some of the delineated low resistivity zones $(3-200 \Omega \mathrm{m})$ present vertical sharp edges, likely created by vertical faults that flank the zones on both sides. The low resistivity of these zones could be attributed to the occurrence of conductive material such as gold and associated base metals which probably exist in pegmatitic veins within the zones.
\end{abstract}

Keywords:Gold Mineralization; Low Resistivity Zones, Vertical Faults; Pegmatitic Veins; Iperindo.

\section{Introduction}

Gold is a precious metal of high commercial value and great economic importance that Nigeria is endowed with. However, the total reserve estimate remains largely unknown owning to inadequate exploration data and unreliable subsurface information where available. This has encouraged artisanal mining (with associated ills such as banditry, communal clashes and environmental degradation) of the resource inplace of commercial exploitation which is able to contribute meaningfully towards the GDP growth of the country. Gold mineralization in Nigeria has been described as orogenic, controlled by deep seated fracture system (Oyinloye and Steed, 1996; Oyinloye, 2011). In the Ilesha and Egbe areas, gold occurs in the amphibolites in concentration above the average primary gold content for similar rocks and it is sufficient to serve as the source of some of the alluvial deposits, occurrence of which have been widely reported by some authors such as Elueze (1981) and Garba (1985).

In this study, Electrical Resistivity Tomography (ERT) geophysical investigation technique was applied to delineate zones of anomalous ground conduction which could be attributed to the occurrence of high gold concentration and associated base metals, in the host rocks of Iperindo in Ilesha schist belt, southwestern Nigeria. Geophysical investigation methods have been successfully used in solving ground water, mining, civil engineering and environmental problems, (Sharma, 1997). Electrical Resistivity Tomography which measures the ease with which electric current flows within the subsurface (Reynolds, 1997) through the determination of potential difference generated between two potential electrodes as a result of flow of injected direct current or low frequency alternating current within the ground has been widely reported to give successful subsurface information (conductivity distribution) useful for evaluating occurrence of metallic deposit (Sharma, 1997).

\section{Geology of the study area}

This work was carried out in Iperindo, part of Ilesha Schist Belt, southwestern Nigeria. It is located between latitude $7^{\circ} 25^{\prime} \mathrm{N}-7^{\circ} 45^{\prime} \mathrm{N}$ and longitude $4^{\circ} 35^{\prime} \mathrm{E}-4^{\circ} 55^{\prime} \mathrm{E}$ (Figure 1), situated within the Basement Complex of southwestern Nigeria. The Basement Complex itself has been reported by several authors to comprise largely of a metasedimentary series with associated minor metaigneous rocks that have been variably altered to migmatitic gneisses, and the Older Granites suite of both intrusive and replacement origin (Jones \& Hockey, 1964: Grant, 1971; Burke et al., 1976). The study area is mainly underlain by granite gneiss (Figures 1 \& 2) and intruded by pegmatite veins as well as quartzite and quartz schist which may be gold bearing. Other rocks in the area include migmatite, quartz feldspathic granulite, gneiss and schist. Most rocks within the study area mainly strike approximately $\mathrm{N}-\mathrm{S}$ and dip between $70^{\circ}-80^{\circ} \mathrm{W}$ in schist and up to 
$80^{\circ} \mathrm{W}$ in quartz schist. The pegmatites and quartz veins generally intruded the host rocks as near vertical dyke with average dip of $75^{\circ}$ having sharp to diffuse contact with the host rocks.

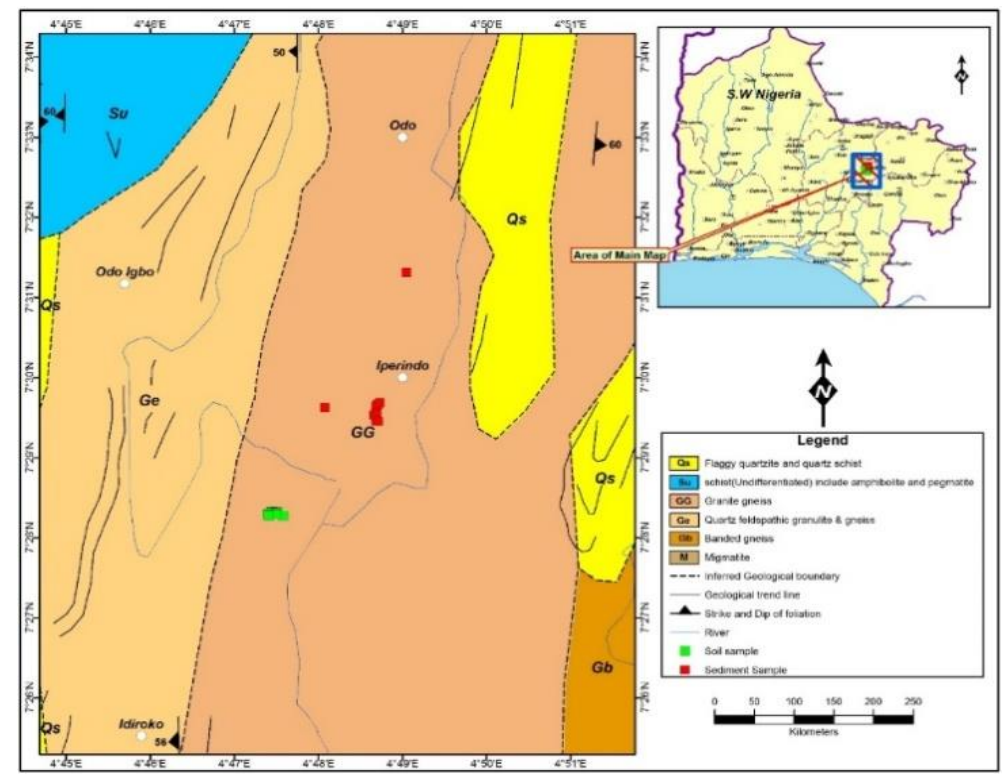

Fig. 1:Geological Map of the Study Area (Adapted From NGSA, 2009).

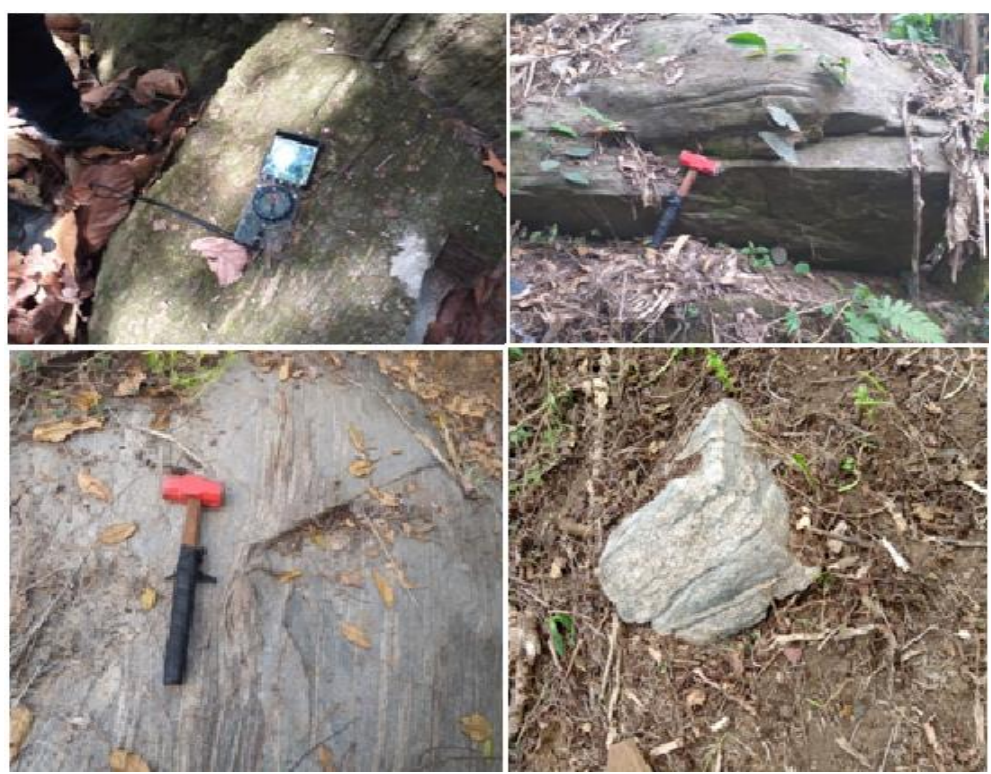

Fig. 2:Some Rock Outcrops in the Study Area.

\section{Materials and methods}

Data acquisition was carried out using multi-electrode Supersting R8/IP/SP resistivity meter (Figures 3) which is capable of simultaneous measurement of ground resistance at different electrode stations along the established profile and thus enabling rapid and less tedious field measurement (Griffiths et al., 1990). 


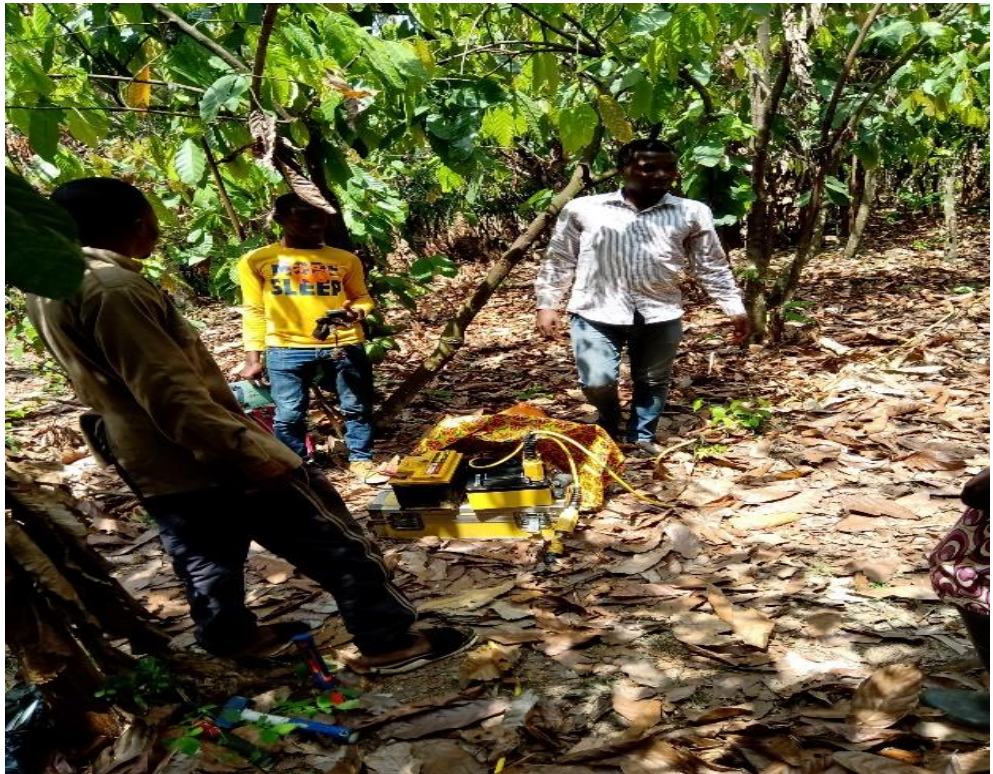

Fig. 3:Geophysical Crew Deploying Supersting R8/IP/SP Geo-Electrical Resistivity Meter, Cables and Electrodes.

Five (5) $336 \mathrm{~m}$ length E-W ERT profiles which run perpendicular to the general geological strike of the study area were established at 10 $\mathrm{m}$ inter profile separation (Figure 4) and occupied using dipole - dipole electrode configuration separated at $3 \mathrm{~m}$ electrode spacing. Individual electrode points were georeferenced, using Global Positioning System (GPS) to record the longitude, latitude and elevation of each electrode station.

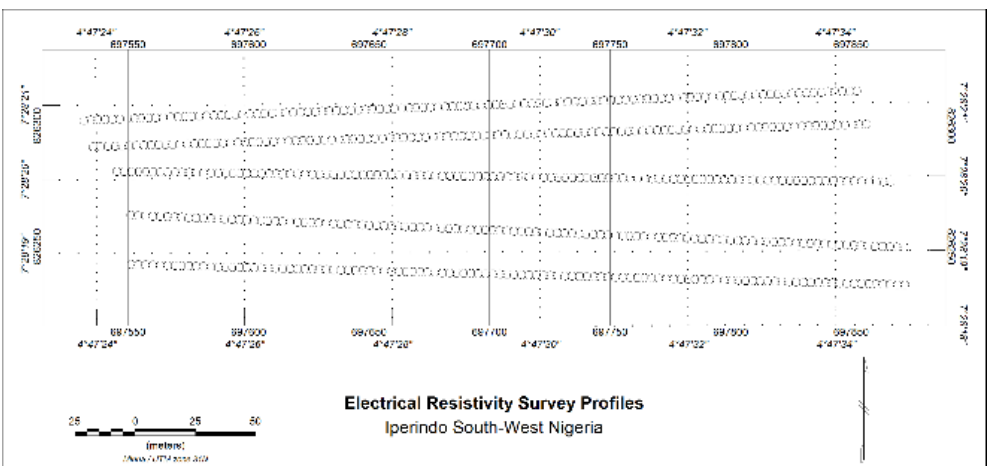

Fig. 4:Electrical Resistivity Tomography Survey Profiles Base Map.

Data processing

The obtained apparent ground resistivity data measured directly by the resistivity meter after the incorporation of the electrode configuration parameter were Quality Check (QC) and evaluated for consistency. Spurious and out ranged individual spiky data with no geological implication were eliminated to improve the Signal to Noise ratio $(\mathrm{S} / \mathrm{N})$. The resultant filtered data were inverted, using RES2DINV inversion software developed by Loke and Baker, (1996) to match the data with corresponding depth and further rid the data of noise, thus generating the true ground resistivity distribution across the occupied profile stations. Inverted and georeferenced individual resistivity point data which have been sorted into different corresponding depths were pooled together using Oasis Montaj visualization software application. The visualization application grid the data using Kriging gridding methods (Chiao et al., 2014) and generate 2D geoelectric sections, maps and 3D subsurface resistivity model. These were employed to evaluate the gold potential of the Iperindo axis of the Ilesha Schist belt in terms of the ground conductivity distribution which is able to delineate zones of anomalous ground conductivity.

\section{Results and discussions}

The processed subsurface resistivity data which indicate the ground resistivity distributions are presented as $2 \mathrm{D}$ geoelectric sections, iso depth resistivity maps, resistivity fence diagrams and 3D subsurface resistivity models which enable the evaluation of the variation in geoelectric properties of the ground in a 3D space (Osinowo et al., 2017; 2018). The various georesistivty results in ohms-meter $(\boldsymbol{\Omega} \mathrm{m})$, obtained from the study, indicate variation in subsurface electrical properties which often reflects changes in rock properties, especially properties that are associated with changes in lithology, porosity, permeability, clay content, degree of fracturing, groundwater saturation or leachate contamination (Friedman, 2005). The filtered and inverted model resistivity section of profile 1 is presented in figure 5a. The profile which trends along $\mathrm{E}-\mathrm{W}$ direction of the study area present subsurface resistivity distribution beneath the $336 \mathrm{~m}$ long profile station and imaged up to $66 \mathrm{~m}$ below the surface. The profile shows resistivity distribution that range in value from 3.41 to $18836 \Omega \mathrm{m}$. The near surface, about $5 \mathrm{~m}$ below the surface, generally display relatively low resistivity distribution which range in value from 3.41 to $137 \Omega \mathrm{m}$. The zone also presents heterogenous resistivity distribution with several isolated zones having very low resistivity value $(<4 \Omega \mathrm{m})$ when compared with adjacent zones that are greater than $100 \Omega \mathrm{m}$ in value. High resistivity values (1500 to $18836 \Omega \mathrm{m})$ generally characterize the deeper part of the subsurface except for the eastern (beginning: $0-90 \mathrm{~m})$ and western $(288-336 \mathrm{~m})$ ends of the profile which present relatively lower resistivity that range in value from $137-469 \Omega \mathrm{m}$, extending up to a depth of $45 \mathrm{~m}$, especially in the eastern part of the profile.The low resistivity zone in the eastern end of the profile display vertical contact with the host rock. The low resistivity zone appears 
like a vertical fractured zone, which reveals a likely structural feature that look like a dyke of low resistivity zone. The zone could be attributed to the occurrence of low resistivity intrusive or emplacement conductive rock unit, emplaced between two vertical faults that flank the zone on both sides. It could also be related to the presence of high density of mineralized veins between the two vertical fractures that flanks the zone on both sides. The mineralized veins could also be saturated with water or clay or a combination of all. Figure $5 \mathrm{~b}$ presents the true resistivity distribution section along profile 2 . The profile section indicate subsurface resistivity distribution that range in value from 1.22 to $9875 \Omega \mathrm{m}$ across the profile station up to $66 \mathrm{~m}$ depth. The near surface, especially upper $20 \mathrm{~m}$, display relatively low but highly varying resistivity distribution having value that range from 4.41 to $60 \Omega \mathrm{m}$ along the profile station (Figure $5 \mathrm{~b}$ ). High resistivity distribution also characterize the deeper part of the sampled subsurface with resistivity distribution value ranging from 1500 to $9876 \Omega \mathrm{m}$ except for relatively low resistivity zone $(14-470 \Omega \mathrm{m})$ existing east of the profile up to a depth of $30 \mathrm{~m}$ below the surface, that occur between $60-160 \mathrm{~m}$ along the profile station. Similar low resistivity zone also exist in the western end (267 - $336 \mathrm{~m})$ of the profile, with the relatively low resistivity zone extending up to $15 \mathrm{~m}$ below the surface.

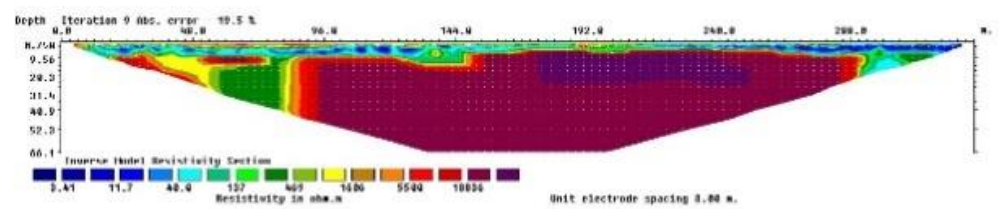

Fig. 5: A) Inverted Resistivity Sections for Profile 1.

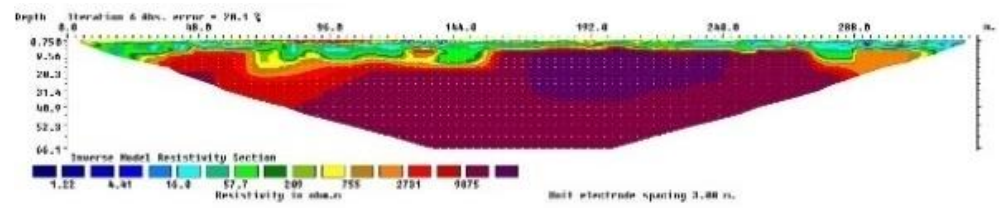

Fig. 5: B) Inverted Resistivity Sections for Profile 2.

The resistivity distribution along the sampled part of profile 3, presented as the inverted 2D resistivity sections is shown in figure $6 \mathrm{c}$. The E - W trending profile present subsurface resistivity distribution value that range from 2.60 to $4572 \Omega \mathrm{m}$ up to a depth of $66 \mathrm{~m}$ beneath the surface. The near surface, extending from $5 \mathrm{~m}$ up to15 $\mathrm{m}$ depth below the surface is generally low and heterogeneous in subsurface resistivity distribution ( 2.60 to $229 \Omega \mathrm{m}$ ). Section of the profile between 144 to $192 \mathrm{~m}$ present relatively low resistivity distribution ( 229 to 2145 $\mathbf{\Omega})$ at depths up to $20 \mathrm{~m}$.

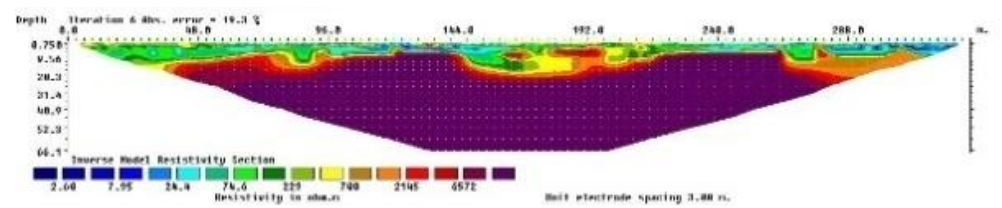

Fig. 5: C) Inverted Resistivity Sections for Profile 3.

Figure $5 \mathrm{~d}$ is the inverted subsurface resistivity section along profile 4.The section indicates subsurface resistivity distribution that range in value from $<1.0$ to $134456 \Omega \mathrm{m}$. Like the resistivity distribution of other profiles, the upper $25 \mathrm{~m}$ below the surface also presents relatively low resistivity distribution. The eastern part of the $\mathrm{E}-\mathrm{W}$ trending profile, from the beginning of the profile up to $192 \mathrm{~m}$ along the profile has relatively low and heterogeneous subsurface resistivity distribution $(58.7-490 \Omega \mathrm{m})$. The depth of the low and heterogeneous region varies and extends up to $25 \mathrm{~m}$ depth in the eastern part of the profile and shallower (around $10 \mathrm{~m}$ ) toward the west $(192-288 \mathrm{~m}$ ). The deeper part of the subsurface ( $>25 \mathrm{~m}$ ) is generally characterized with very high subsurface resistivity distribution which is often in excess of $15000 \Omega \mathrm{m}$. The resistivity range here likely corresponds to the resistivity distribution of fresh / unfractured basement complex rocks.

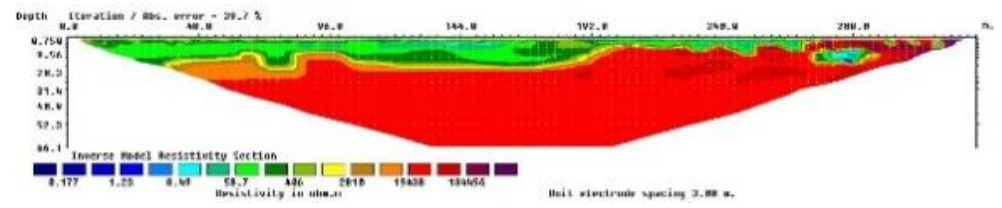

Fig. 5: D) Inverted Resistivity Sections for Profile 4.

Figure 5e shows the subsurface resistivity section along Profile 5. The section presents subsurface resistivity distribution that range in value from 4.91 to $87000 \Omega \mathrm{m}$ up to a depth of $66.1 \mathrm{~m}$. The near surface generally present low resistivity distribution with the eastern end of the profile, especially between $70-170 \mathrm{~m}$ along the profile having low resistivity value $(21.6-418 \Omega \mathrm{m})$ with the section between $126-170$ presenting lower resistivity distribution $(21.6-95 \Omega \mathrm{m}$ ) that extends up to $30 \mathrm{~m}$ below the surface. The western end likewise shows relatively low resistivity distribution from around $250 \mathrm{~m}$ to the end of the profile $(366 \mathrm{~m})$. Here the low resistivity zone extends up to $40 \mathrm{~m}$. The near vertical boundary of the low resistivity zones suggests association of the zone with vertical faults which flank the zones on both sides. The low resistivity zones are likely composed of several smaller sets of fractures or veins that are likely filled by conductive gold or / and base metals. The zones are likely also saturated with water since the zones may be well fractured.

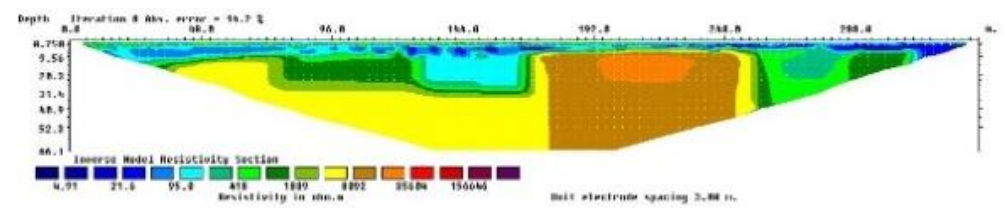


Fig. 5: E) Resistivity Distribution Section Along Profile 5.

The integrated individual georeferenced, filtered, inverted and depth sorted resistivity data obtained from all the occupied electrode stations along all the five (5) profiles generated 3D subsurface resistivity distribution of the study area (Figure 6). The $40 \mathrm{~m}$ by $336 \mathrm{~m}$ by $67.5 \mathrm{~m}$ $3 \mathrm{D}$ resistivity distribution image shows resistivity variation along the $\mathrm{x}, \mathrm{y}$ and $\mathrm{z}$ directions. The image indicates that resistivity value range from $<463.72$ to $14373.10 \Omega \mathrm{m}$ across the entire study area. The 3D resistivity image generally indicate dominantly high resistivity distribution ( $>463$ to $14373 \Omega \mathrm{m}$ ) across the study area with isolated low resistivity zones $(<463 \Omega \mathrm{m})$ restricted to the eastern and western ends of the study area. The image also shows that the relatively low resistivity region occur shallow and close to the surface, occurring not more than $40 \mathrm{~m}$ where it occurred deepest (Figure 7). The central part of the model reveals high resistivity values $(6913.51$ to $14373.75 \Omega \mathrm{m}$ ) which likely correspond to the occurrence of fresh / unweathered Basement Complex of southwestern Nigeria. The image also indicate that more than $80 \%$ of the lower part of the model, corresponding to the fresh unfractured basement rock, has high resistivity values (10773.19 to $14373.75 \Omega \mathrm{m})$

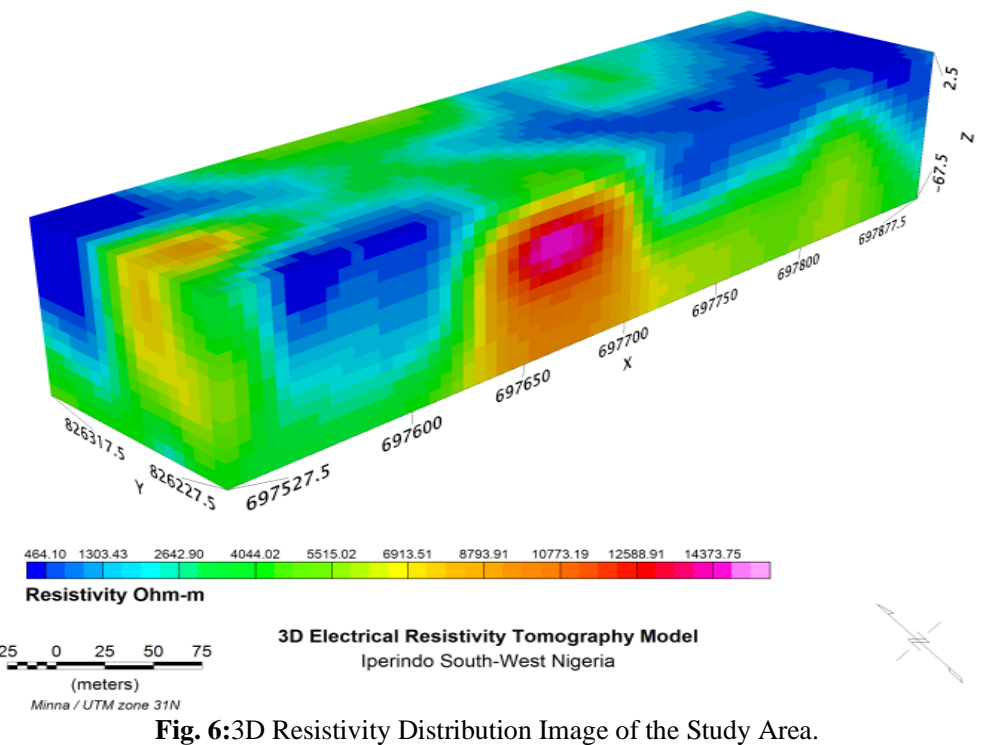

Fig. 6:3D Resistivity Distribution Image of the Study Area.

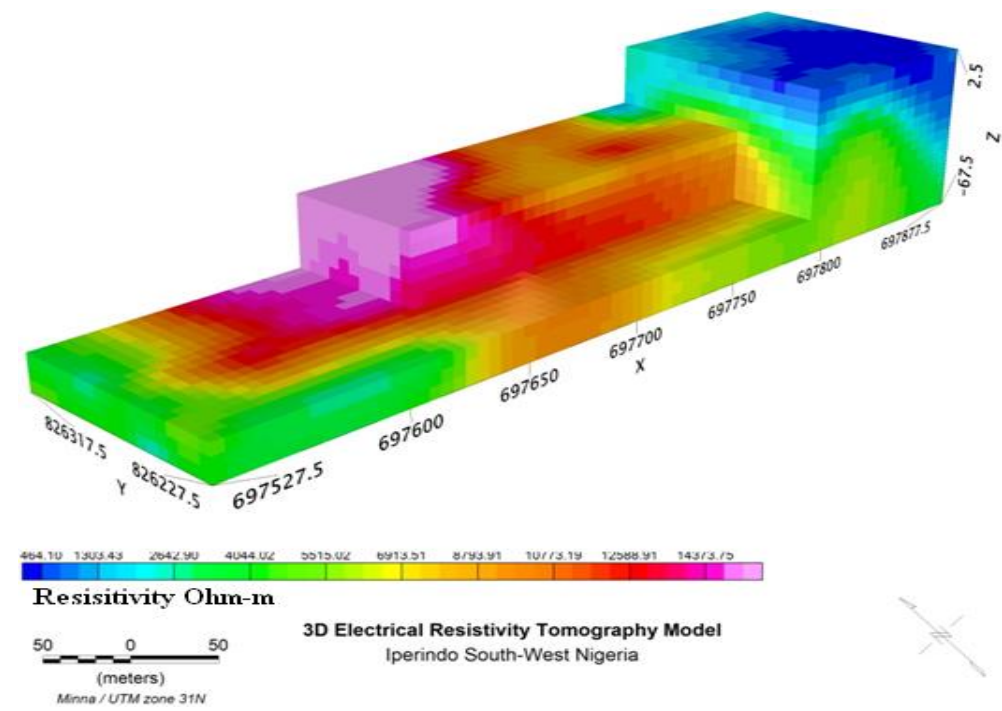

Fig. 7:Sliced ERT Resistivity 3D Model to Reveal Desired Parts of the Model.

Iso depth surface resistivity distribution maps extracted from the 3D image is presented in figure 8. The figure shows seven (7) depth resistivity distribution maps extracted at $2 \mathrm{~m}, 10 \mathrm{~m}, 20 \mathrm{~m}, 30 \mathrm{~m}, 40 \mathrm{~m}, 50 \mathrm{~m}$ and $60 \mathrm{~m}$ to evaluate the variation in resistivity with depths across the study area. The iso depth resistivity distribution map at $2 \mathrm{~m}$ depth display near surface resistivity distribution pattern which is dominantly low and heterogeneous $(<463.72-500 \Omega \mathrm{m})$ in nature. The iso depth resistivity maps indicate that the subsurface resistivity distribution across the study area gradually increases with depth. At $10 \mathrm{~m}$ depth, the resistivity distribution varies from 463.72 to $8794 \mathbf{\Omega m}$ which dominantly indicate relatively low resistivity distribution, such as consistent to near surface environment. However, the distribution is slightly higher than at $2 \mathrm{~m}$. A patch of relatively high resistivity $(8794 \Omega \mathrm{m})$ zone is visible on the $10 \mathrm{~m}$ depth resistivity distribution map. The lateral extent as well as the resistivity value of the pattern gradually increases with depth. At $60 \mathrm{~m}$ below the surface, the high resistivity $(8794 \Omega \mathrm{m}-14373.10 \Omega \mathrm{m})$ zone almost extend to cover the entire study area safe for eastern and western flanks of the study area, having characteristic lower resistivity values $(4041-5516 \Omega \mathrm{m})$. 


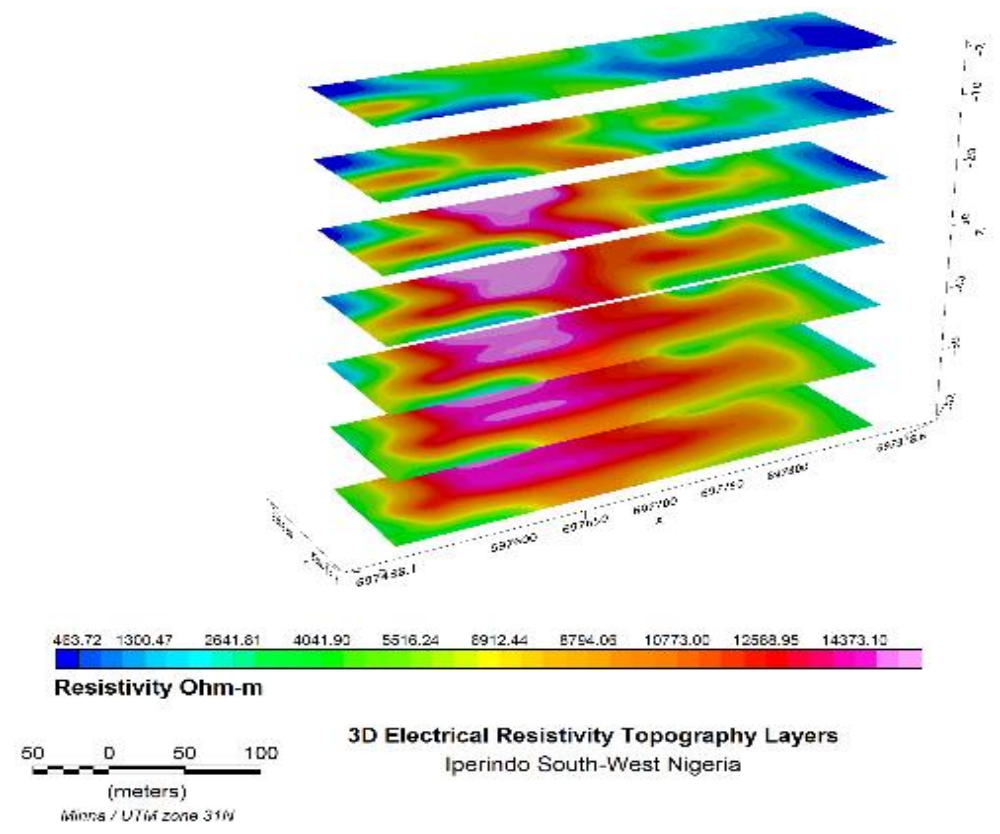

Fig. 8:Iso Depth Resistivity Map Across the Study Area.

Figure 9 presents resistivity fence diagram constructed from sets of $\mathrm{N}-\mathrm{S}$ and $\mathrm{E}-\mathrm{W}$ trending resistivity distribution sections which intersect themselves at right angles. The diagram, generated from the 3D resistivity model enables the evaluation of the variation of the resistivity pattern along some of the established profiles as well as across some intersecting sections. This way the pattern of resistivity distribution of the subsurface of the studied part of Iperindo situated in Ilesha Schist belt of southwestern Nigeria is appreciated. The resistivity fence present resistivity distribution that range from 464.10 to $14373.75 \Omega \mathrm{m}$, with some isolated zones of low resistivity values $(<464 \boldsymbol{\Omega m})$ situated on some of the intersecting section walls of the fence. The zones of low resistivity as observed from the fence are restricted to the upper parts of the section walls.

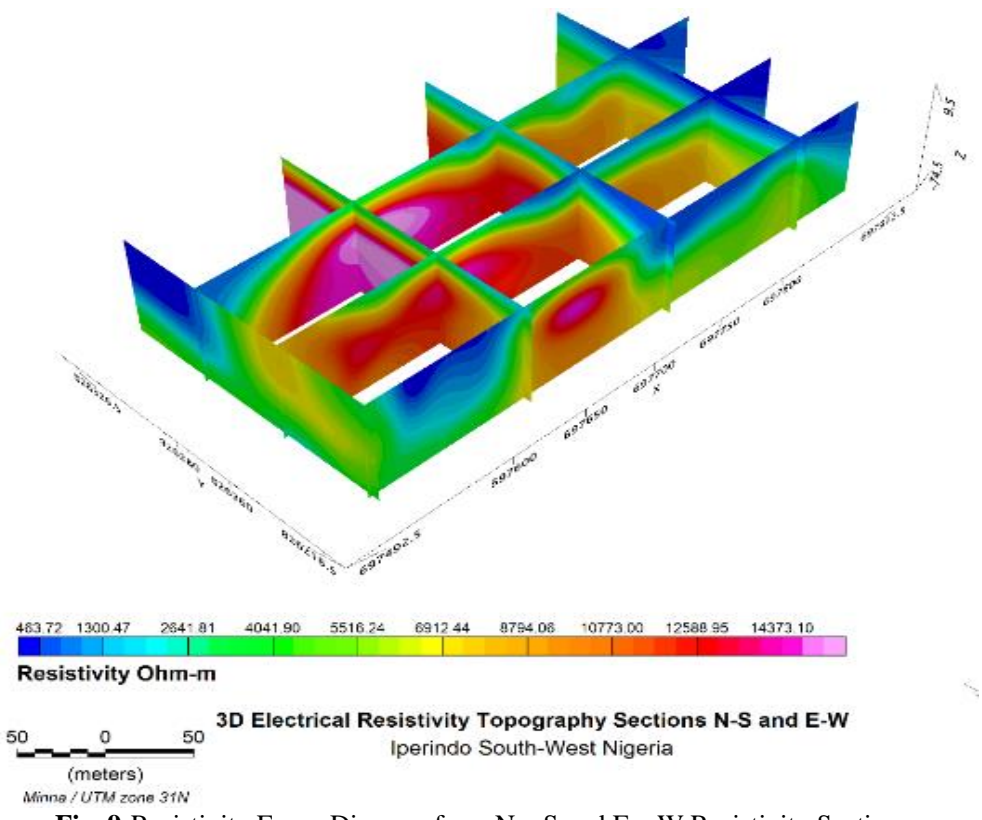

Fig. 9:Resistivity Fence Diagram from N - S and E - W Resistivity Sections.

The evaluation of electrical resistivity data generated from five (5) sets of $\mathrm{E}-\mathrm{W}$ trending profiles occupied at a part of Iperindo in Ilesha Schist belt southwestern Nigeria has identified some isolated zones of low resistivity distribution together with well distributed and extensive zone of high resistivity zone. The high resistivity value likely correspond to fresh, unfractured and unweathered Basement Complex rocks of part of the Schist belt in southwestern Nigeria. On the other hand, the low resistivity zones which appeared mostly situated close to the surface are likely structurally controlled judging from the displayed linear vertical bounding edges that appeared associated with two vertical faults that flank some of the low resistivity zones on both sides. Some of the shallow low resistivity zones are mostly restricted to eastern and western ends of the study area. The low resistivity zones flanked by two vertical faults likely composed of several other fractures and veins situated between the two major upright vertical faults. The veins appear to be saturated with conductive materials such as base metals, gold, groundwater or clay. The conductive materials likely occur in association with pegmatitic veins which are possibly mineralized. 


\section{Conclusion}

The imaging ability of electrical resistivity tomography has been demonstrated in this study to evaluate gold mineralization potential of part of Iperindo in Ilesha Schist belt, southwestern Nigeria. The study identified relatively shallow low resistivity zones which are mostly restricted to the eastern and western ends of the study area as candidate area with possible mineralization of gold or other base metals occurring in pegmatitic veins situated within the low resistivity zones. The low resistivity zones, some of which are as deep as $40 \mathrm{~m}$ from the surface can be validated with geochemical drilling to quantitatively evaluate the gold mineralization potential of the area. The importance of subsurface information as such generated from geophysical investigation cannot be overemphasized, especially to generate requisite subsurface information for commercial development of gold mineralization potential of the Ilesha Schist belt. This could generate royalty tax for the government and employment for the inhabitants instead of the thriving artisanal mining activities in the area.

\section{Acknowledgement}

The authors appreciate Pan African University for providing fund for this study.

\section{References}

[1] Burke, K.C., Freeth, S.J. and Grant, N.K. (1976). The Structure and Sequence of GeologicalEvents in the Basement Complex of Ibadan Area, Western Nigeria, Prec. Res. Vol. 3 No. 6,1976.https://doi.org/10.1016/0301-9268(76)90017-6.

[2] Chiao, L., Chen, Y., Gung, Y., 2014. Constructing empirical resolution diagnostics forkriging and minimum curvature gridding. J. Geophys. Res.: Solid Earth 119 (5), 3939e3954.https://doi.org/10.1002/2013JB010364.

[3] Elueze, A. (1981). Petrographic studies of metabasic rocks and meta-ultramafites in relationto mineralization in Nigerian schist belts. J. Min. Geol, 18(1), 31-36.

[4] Friedman, S.P., 2005. Soil properties influencing apparent electrical conductivity. Comput.Electron. Agric. 46, 45e70.https://doi.org/10.1016/j.compag.2004.11.001.

[5] Garba, I. (1985). Geological and geochemical investigations of the gold occurrences north ofIsanlu, Kwara State, Nigeria. Unpublished M. Sc. Thesis, Ahmadu Bello University, Nigeria.

[6] Grant, N.K. (1971). South Atlantic, Benue Trough and Gulf of Guinea Cretaceous TripleJunction. Bull. geol. Soc. Am. 82,22952298.https://doi.org/10.1130/0016-7606(1971)82[2295:SABTAG]2.0.CO;2.

[7] Griffiths, D.H., Turnbull, J. and Olayinka, A.I. (1990). Two-Dimensional ResistivityMapping with a Computer-Controlled Array. First Break, 8, 121-129.https://doi.org/10.3997/1365-2397.1990008.

[8] Jones, H. A., and Hockey, R. D. (1964). The Geology of Part of Southwestern NigeriaGeological Survey of Nigeria (Bulletin 31), 1-101.

[9] Loke M.H. and Barker, R.D. (1996). Rapid Least-Squares Inversion of Apparent ResistivityPseudosections by a Quasi-Newton Method. Geophysical Prospecting, 44, 131-152.https://doi.org/10.1111/j.1365-2478.1996.tb00142.x.

[10] NGSA (2009). Nigerian Geological Survey Agency's Lineament and Geological Map of Nigeria, Scale 1:100 000.

[11] Osinowo, O. O., Agbede, O. A. and Olayinka, A. I. (2017). Application of ElectricalResistivity Imaging (ERI) Geophysical Technique to Determine

[12] Causes of Stress InducedCracks Observed on Office Building Complex within University of Ibadan Campus, Ibadan,Southwestern Nigeria. Journal of Mining and Geology, Vol.53(1), pp. $31-44$.

[13] Osinowo, O. O., Falufosi, M. O., \&Omiyale, E. O. (2018). Integrated electromagnetic (EM)and Electrical Resistivity Tomography (ERT) geophysical studies of environmental impact ofAwotan dumpsite in Ibadan, southwestern Nigeria. Journal of African Earth Sciences, 140,42-51. https://doi.org/10.1016/j.jafrearsci.2017.12.026.

[14] Oyinloye, A. O. (2011). Geology and Geotectonic Setting of the Basement Complex Rocks in Southwestern Nigeria: Implications on Provenance and Evolution. Earth and Environmental Sciences, 98 - 117.

[15] Oyinloye, A. O. and Steed, G.M. (1996). Geology and Geochemistry of the Iperindo Primary gold deposits Ilesha schist belt Southwestern Nigeria. Inferences from stable carbon isotope studies. Africa J. Sc. Tech. 8 (1) pp 16-19.

[16] Reynolds, J.M., 1997. An Introduction to Applied and Environmental Geophysics, vol.2. John Wiley and Sons Ltd., West Sussex, p. 796.

[17] Sharma, P.V., 1997. Environmental and Engineering Geophysics. Cambridge UniversityPress, pp. 173.https://doi.org/10.1017/CBO9781139171168. 